\title{
Tangyin Rift Tectonic Evolution and Paleozoic Thermal Storage Genetic Mechanism
}

\author{
Yan Ge, Xin Du \\ No.2. Institute of Geo-Environment Survey of Henan \\ Zhengzhou, China \\ e-mail: geyansun@163.com \\ Xianguo Wang \\ Henan Bureau of Geo-exploration and Mineral \\ Development \\ Zhengzhou, China \\ e-mail: geyansun@163.com
}

\author{
Wenjuan Wang \\ No.2. Institute of Geo-Environment Survey of Henan \\ Zhengzhou, China \\ e-mail: geyansun@163.com
}

\begin{abstract}
Late Proterozoic, Luliang movement made vast areas of North China into the sector development period. Early Cambrian, North China block sank as a whole, depositing a 500 to 1400 meters stable carbonate sedimentary rocks. Jurassic - Cretaceous, Tangxi fracture and Tangdong fracture started to move, Tangyin depression took its shape. Late Cretaceous, under the strong influence of Yanshan movement, Tangyin depression uplifted along both sides of the swell. Late Eocene, under the strong influence of Xishan movement, Tangxi fracture and Tangdong fracture moved more strongly. Tangyin depression formed Cenozoic sedimentary places by lifting into settlement.Due to far extending and bigger dropping, two deep fractures controlled Tangyin depression's occurrence and development.Fractures' strong activity , sedimentary deposit and the evolution of Tangyin depression provided a good thermal storage reservoir, cover, pass, source conditions for formation of Paleozoic geothermal reservoir.Close to the swell, tectonic activity was strong,karst fissures was developed and geothermal reservoir's temperature was high
\end{abstract}

Keywords-depression; paleozoic; ordovician; fracture; geothermal reservoir

\section{INTRODUCTION}

Tangyin depression was located at the southern end of Taihang foothill and spreaded in Anyang, Xinxiang and Hebi area.The depression was Cenozoic-elongated, towards NNE.Tangxi fracture broke the boundary of Taihang Mountains swell on the west side.Tangdong fracture broke the boundary of Neihuang swell on the east side. see Figure 1.

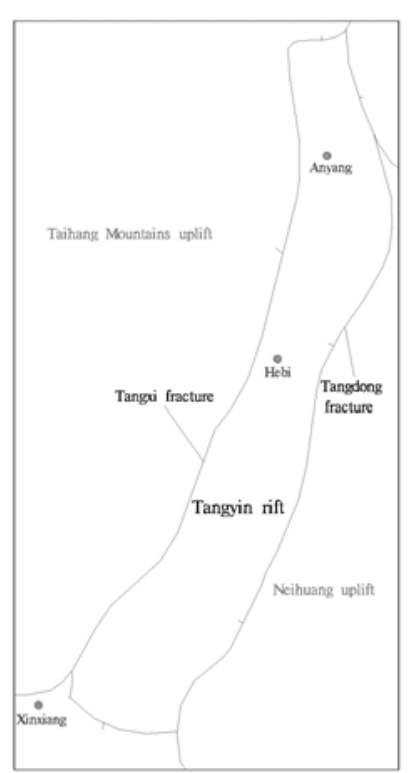

Figure 1 Tangyin depression structural outline map

Locating in east and west sides of the boundary, Tangxi and Tangdong fractures were basement deep faults, extending far, a large gap, controlling Tangyin depression's occurrence and development. Tangxi fracture, north Tangyin, southwards through Miaokou, Qingyangkou, Xinxiang to Westwangcun, about 100 kilometers long, towards the north east 15 to 25 degrees, south east tendency, inclination greater than 45 degrees, falls $1000 \mathrm{~m}$. The main activity phase was Yanshan and Himalayan periods. Tangdong fracture, from Hebei province to Henan Xiangbiji Baiying, shangdang - Yulin area, about 110 kilometers, towards the north east 25 degrees, tended to the north west, generally more than 40 degrees inclination. There was a seismic activity belt along this fault. 


\section{TANGYIN DEPRESSION EVOLUTION COURSE}

Archean, North China formed a uniform crystalline basement on the base of Wutai sports . Late Proterozoic, Luliang movement made vast North China region into the sector development period. Jinning movement made North China Plate generally uplifted. Early Cambrian, due to mild climate, sea level rising, salt water intrusion, invertebrates trilobites, graptolites heyday, a large-scale biological big bang occured.The North China block sank as a whole under the influence and deposited a 500 to 1400 meters stable carbonate sedimentary rocks. Late Triassic, affecting by the Indo-China campaign, North China gradually slowly uplifted.

Jurassic - Cretaceous, derived a series of normal faultswith along with the Pacific plate's the westward migration. Tangxi and Tangdong fractures began to break, Tangyin depression got its embryonic form. With two boundary fault activity intensity increasing, ancient stratas on the east and west sides bulge suffered serious erosion, Gap between the top surface of the Ordovician was up to 8000m.

End of the Cretaceous, under the strong influence of Yanshan movement, the depression uplifted along both sides of swells, missing Mesozoic sedimentary. Late Eocene, on the basis of Yanshan period ancient structure, Himalayan movement strongly influenced the region.Tangxi and Tangdong fractures moved more intensely. Tangyin depression converted from uplifting to squatting and caused Cenozoic sedimentary strata place .

Oligocene was the major development period. Due to the narrow-long north-south, narrow east-west , combined with ample supplies provenance, deposition speed, under the influence of two border NNE faulting, deposited $4000 \mathrm{~m}$ thick fluvial phase red sandstone and mudstone. Late Oligocene, gradually settling into rising, lake shrinking, regional erosion began.

After Neogene, a large area of stable settlementthe began. Tangyin depression deposited nearly 1000m thick Neogene lacustrine sandstone and mudstone floodplain. Late Pliocene-Quaternary early on, at the same time faulting, accompanied by a mafic - ultramafic intrusive rocks.Along Tangxi fracture occured volcanic activity.

In short, Tangxi and Tangdong -two basement boundary faults controlled the evolution of Tangyin depression.

\section{PALEOZOIC THERMAL STORAGE GENETIC MECHANISM}

Tangyin depression is located at the eastern foot of Taihang uplift, basement lithologies being Archean, Paleozoic, overlying layer being Mesozoic and Cenozoic, see Figure 2.

Two basement boundary fractures controlled the formation of Paleozoic geothermal reservoir. No.2 well located near Tangxi fracture. Geothermal reservoir was Ordovician limestone, limestone fissures were developed. Automatic water quantity was $1847 \mathrm{~m}^{3} / \mathrm{d}$, wellhead pressure 2.2Mpa, bottomhole temperature $117{ }^{\circ} \mathrm{C}$, the water temperature $74^{\circ} \mathrm{C}$. No.3 well was about $1 \mathrm{~km}$ away from No.2,being farther away from the fracture. It's Automatic water quantitywas only $35 \mathrm{~m}^{3} / \mathrm{d}$, wellhead pressure $1.5 \mathrm{Mpa}$, water temperature $58^{\circ} \mathrm{C}$. see Figure 3 and Figure 4.

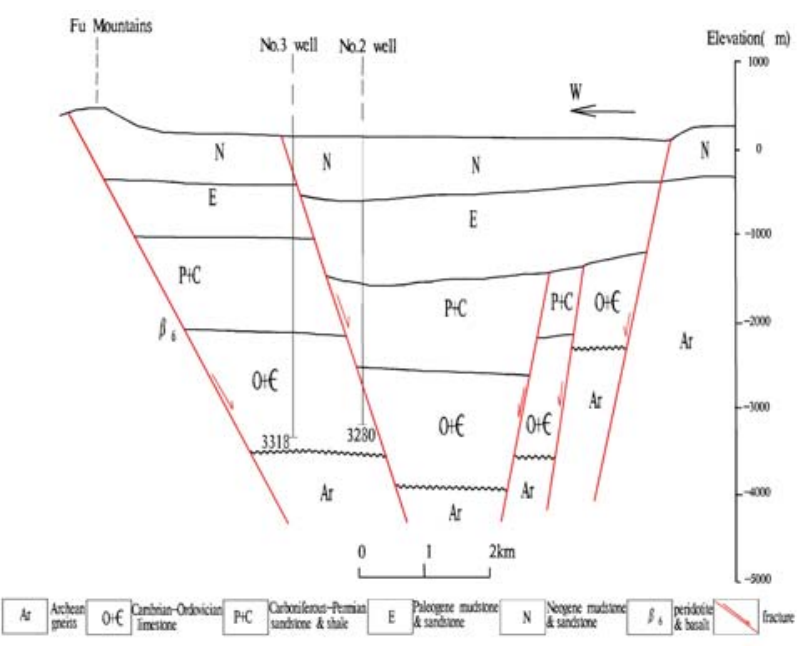

Figure 2 Tangyin depression schematic cross sec-tion

Tangyin depression had the formation of Paleozoic geothermal field reserve, cover, pass, source conditions(GE.2008).

"Reserve": geothermal reservoir lithology were Cambrian, Ordovician limestone.Limestone fissures were more developed ,being high degree dissolution(GE.2012). Created favorable conditions for the storage of underground water, and constituted a good thermal reservoir in this area .

"Cover": Carboniferous, Permian dense sandstone and shale, and Paleogene lacustrine red mudstone composed thick thermal reservoir cap (E. 2010)..

"Through": Two basement faults opening degree turned better. In general, there was a direct link between the opening degree fault and the deep underground hot water. Because of broken rocks, developed cracks, easy to occur and transport and enrich various ions. These places would become geothermal fluids' favorable position. Geothermal fluids could enrich in these faults and circulate along these channels. So these faults and cracks would be a good channel of hot water.

"Source": the main recharg source of groundwater was from the western mountains' rainfall. Uplifted Taihang Mountains' elevation was in $1500 \sim 1800 \mathrm{~m}$. Vast geographical, permeability rocks became the major hot water recharge areas. The uplifted area Covering by Paleozoic, Mesozoic and Cenozoic near Tangxi fracture easily tended to concentrate heat fluid along the lower thermal resistance parts due to high thermal conductivity and low thermal resistance of the dense ancient rocks.So the uplifted area near the fracture would be easy to appear high temperature. The geothermal fluid upwelling along the fracture sprayed the surface under the influence of rock pressure after warming heated rocks.Formed flowing well (spring), such as No. 2 well (B. 2012). 


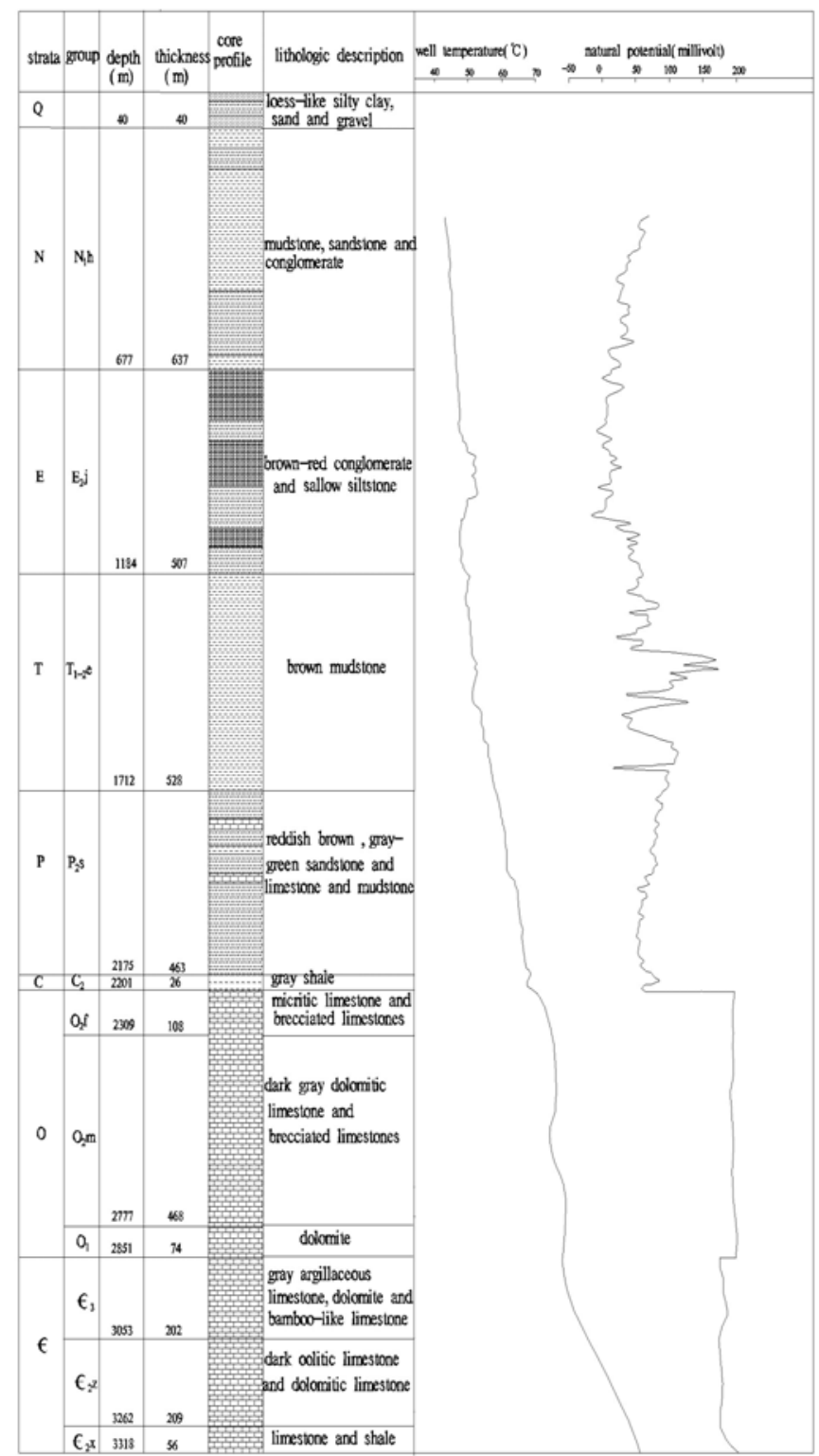

Figure 3 N0.2 well stratigraphic column

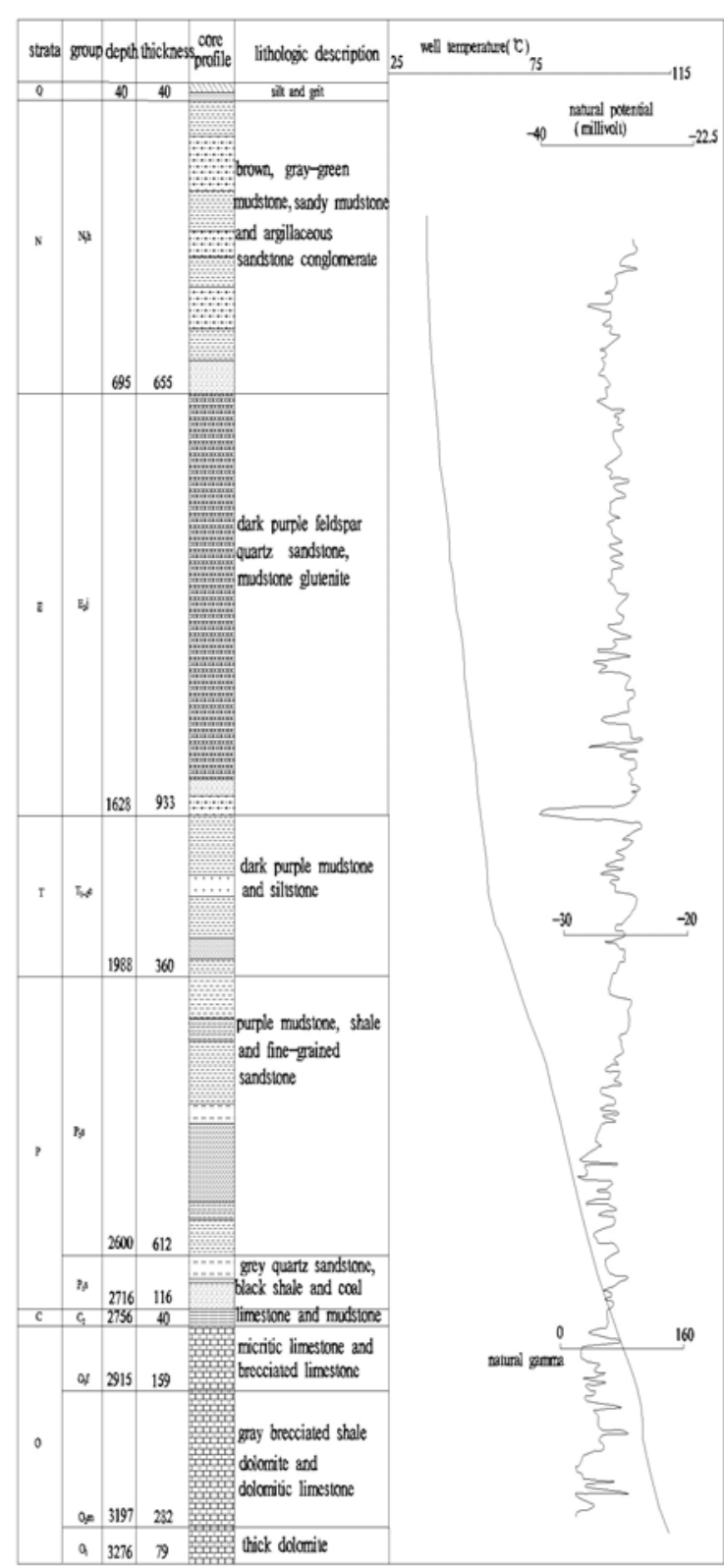

Figure 4 N0.3 well stratigraphic colum

\section{CONCLUSIONS}

Fractures' strong activity, sedimentary deposit and the evolution of Tangyin depression provided a good thermal storage reservoir, cover, pass, source conditions for formation of Paleozoic geothermal reservoir. A high degree of dissolution Cambrian, Ordovician limestone constituted aquifer in this area; Carboniferous, Permian dense sandstone and shale, and Paleogene lacustrine red mudstone composed thick thermal reservoir cap. The opening better basement faults and cracks would be a good channel of hot water.The uplifted Taihang Mountains became the major hot water recharge areas.

Close to the swell, tectonic activity was strong,karst fissures was developed and geothermal reservoir's temperature was high.

Therefore, Tangyin depression had the four favorable conditions for the formation of Paleozoic geothermal reservoir and a good supporting combination relation, with good research value and broad resources prospects. 


\section{REFERENCES}

[1] Yan,GE. Xianguo,WANG..2008.Analysis on genesis of geothermal resources in lingbao basin[J].Yellow River 30 (10): 55-56.

[2] Yan, GE. Xianguo,WANG..2012.Analysis on isotope characteristics of groundwater in lingbao basin[J].Yellow River 34(4): 48-54.

[3] Xianguo,WANG..Yan,GE.2012.Simulation analysis of hydrothermal variation characteristics during water-source heat pumps running[J].Water Resource and Power 30(2): 139-141.

[4] Jiyang, WANG. Zhanxue,SUN .2001.Magic geothermal resource[M].Beijing:Tsinghua University Press, Guangzhou:Jinan University Press.

[5] John W. Lund.2003. Direct-use of geothermal energy in the USA, Applied Energy 74(2003) 33-42.
[6] IUGS. 2004.32nd Internationsl Geological Congress Abstracts[CD].Florence, Italy,20-28 August, p1230-1236.

[7] E. Glowacka, O. Sarychikhina, and F.A.Nava. 2005.Subsidence and Stress Change in the Cerro Prieto Geothermal Field, B.C. Mexico [J]. Pure and Applied Geophysics,162(11): 2095-2110.

[8] Huenges, E. 2010.Geothermal Energy Systems: Exploration Development and Utilization[M].German:Wiley-VCH:406.

[9] Luo C, Huang L C,Gong Y L.2012.Thermodynamic comparison of different types of geothermal power plant systems and case studies in China[J].Renewable Energy 48:155-160.

[10] Ruggero, B. 2012.Geothermal power generation in the world 20052010 update report [J]. Geothermics,41:1-29. 